\title{
Synthesis and Antimicrobial Schreening of New 4,5,6,7-Tatra Hydro Benzo Thiophene Derivatives
}

\author{
Zainab Zuhair Mohammed Ali*
}

Received 5/4/2018, Accepted 13/12/2018, Published 11/3/2019

Asmaa M. Abdulla

This work is licensed under a Creative Commons Attribution 4.0 International License.

\begin{abstract}
:
A group of derivatives for compounds 2-Amino-3-carboxy-4,5,6,7-tetra hydrobenz -othiophene bearing different heterocyclic moieties such as Schiff bases. B-Lactum, 4-thiazolidinone.1,3-oxazepan. The newly synthesized derivatives have been supported by spectral data FT-IR, $\mathrm{H}^{1}$-NMR. All the synthesized compounds were screened for their antimicrobial activities against gram-positive and gram-negative bacteria as reference.
\end{abstract}

Key words: Antimicrobial Activity,2-Azetidinone,3-Oxazepane4-Thiazolidinone, Schiffbases, Tetrazole, Tetra hydrobenzo thiophene.

\section{Introduction:}

Heterocyclic chemistry comprises at least half of all organic chemistry research worldw -ide. In particular, hetrocyclic structures form the basis of many pharmaceutical,agrochemical and veterinary products.Cyclohexanone derivatives play an important comounds(1). Many herbicides having cyclohexanone backbone such as tralkoxydim, sethoxydim or clethodimare well known(2,3). In previous work we were synthesis and biological evaluation of tetrahydrobenzo [b].thiophene as anticancer agent(4).A large number of tetrabenz othiophene derivatives $(5,6,7)$ have been found to important tools of pharmaceutical activity such as antimicrobial, anti-inflammatory and anti HIV.A number of synthetic compounds such as tetrabenzothiophene(8), thiozoldine(9),tetrazole(10

$\%$ ),oxazepin(11) have also been play role exploited for antioxidant activity. Schiff bases is nitrogen analog aldehyde or ketone in which the $(\mathrm{C}=\mathrm{O})$ group is replaced by $\mathrm{a}(\mathrm{C}=\mathrm{N})$ group $(12)$. Has the apparent number of apply in many field including medicine, life science and chemical sciences and interesting biological activities, such as antibacterial(13)antifungal(14) anticancer(15)and herbicide activates(16). Furthermore derivatives of Schiff base azelidinone (B-Lactum) ring (17) are class of important compounds in medicinal chemistry and pharmaceutical field the 4thiazolidenone scaffold is very versatile and has featured in a number of medicinal chemistry(18).

Chemistry department,College of Science, Mustansiryah University, Baghdad, Iraq.

*Corresponding author: zainab_zuhair@yahoo.com
While the tetrazole is one of organic heterocyclic compounds containing a (5) member di unsaturated ring structure compound of (4) nitrogen atom and one carbon are important role such as antibacterial, antiviral, analgesic ,anti-inflammatory (19).Also oxazepin derivatives is a (7) membered ring that contains two heteroatoms(oxygen \& nitrogen)that are available in medicinal chemist and in many pharmaceutical application(11).Also thiadazole and its derivatives are important organic reaction intermediates and they have been widely used as anticonvulsant, antidepressant, analgesic, antiinflammatory, antiplatelet, antimalarial, antiviral, diuredic and muscles relaxant activity(20). In view of these observing we thought that it would be interesting to synthesize the substituted derivative starting from[2-amino-3-carbethoxy$4,5,6,7$,tetrahyroben zothiophene] followed by cyclization of Schiff bases lead to compounds with interesting antibacterial profile.

\section{Materials and Methods:}

Melting point has been specified in open capillary Electro thermal apparatus and is uncorrected.FT-IR measurement were recorded on shimadzudel Infrered spectra-84005. $\mathrm{H}^{1}$-NMR spectra were obtained with a Bruker spectrophotometer model ultra-shield at $300 \mathrm{MHz}$ in DMSO-d $\mathrm{d}^{6}$ solution as a solvent with the TMS as internal reference in this study were reagents grade and they are available from sigma-Aldrich and Fluka companies. Purity of the compounds was checked on silica coated merck-TLC plates using, 
chloroform, benzene and a mixture of hexan and ethyle acetate as mobile phase.

Synthesis of compound(1)[ ethyl 2-amino-4,5,6,7tetrahydro-1-benzothiophene-3-sulfinate]: To a mixed of cyclohexanone $(0,05 \mathrm{~mol}, 4.9 \mathrm{gm})$, ethyl cyanoactate $(0.05 \mathrm{~mol}, 5.65 \mathrm{gm})$ and Sulp -hur $(0.05 \mathrm{~mol}, 1.6 \mathrm{gm})$ in ethanol $(50 \mathrm{ml})$, dipropylamine $(0.05 \mathrm{~mol}, 5.05 \mathrm{gm})$ was added drop wise with stirring. The reaction was reflux for (10hrs).The residue of solvent was evaporated and the crystals was filtered off solvent off, purification from ethanol yield (95\%), m.p(119-121C), FTIR $\left(\mathrm{KBr}, v \mathrm{~cm}^{-1}\right): \quad 1734 \quad(\mathrm{C}=\mathrm{O})$ of $\quad$ ester,2847-2978 $\left(\mathrm{CH}_{2}\right)_{\text {alph }}, \quad 3302-3396\left(\mathrm{NH}_{2}\right), 698(\mathrm{C}-\mathrm{S}-\mathrm{C}) . \quad \mathrm{H}^{1} \mathrm{NMR}$ (300MHz, DSO-d $\left.{ }^{6}, \quad 8, p p m\right): 1.25 \quad$ (t. $3 \mathrm{H}$, $\mathrm{COOCH}_{2} \mathrm{CH}_{3}, 4.30\left(9,2 \mathrm{H}, \mathrm{COOCH}_{2} \mathrm{CH}_{3}\right), 5.5(\mathrm{~s}, 2 \mathrm{H}$, $\left.\mathrm{NH}_{2}\right),(2.01-2.2)\left(\mathrm{m}, 4 \mathrm{H}, \mathrm{CH}_{2}\right), 1.7\left(\mathrm{t}, 2 \mathrm{H}, \mathrm{CH}_{2}\right)$. The physical properties listed in table (1).

Table1. Physical properties of synthesized compound.

\begin{tabular}{cccccc}
\hline Comp. No. & M.P. ${ }^{\circ} \mathrm{C}$ & Yield $\%$ & Recry. Solvent & Color & Molecular Formula \\
\hline 1 & $119-121$ & 95 & Ethanol & Brown & $\mathrm{C}_{11} \mathrm{H}_{15} \mathrm{O}_{2} \mathrm{NS}$ \\
2 & $109-112$ & 85 & Ethanol $+\mathrm{H}_{2} \mathrm{O}$ & Yellow & $\mathrm{C}_{10} \mathrm{H}_{14} \mathrm{~N}_{4} \mathrm{~S}_{2} \mathrm{O}$ \\
3 & $116-118$ & 60 & Ethanol+H $\mathrm{H}_{2} \mathrm{O}$ & Gray & $\mathrm{C}_{10} \mathrm{H}_{12} \mathrm{~N}_{4} \mathrm{~S}_{2}$ \\
4 & $212-214$ & 50 & Ethanol & Yellow & $\mathrm{C}_{24} \mathrm{H}_{20} \mathrm{~N}_{6} \mathrm{O}_{5} \mathrm{~S}_{2}$ \\
5 & $230-232$ & 43 & Chloroform & Black & $\mathrm{C}_{24} \mathrm{H}_{20} \mathrm{~N}_{4} \mathrm{~S}_{2} \mathrm{OCl}_{2}$ \\
6 & $250-252$ & 69 & Benzene & Off white & $\mathrm{C}_{24} \mathrm{H}_{22} \mathrm{~N}_{12} \mathrm{~S}_{2} \mathrm{O}_{5}$ \\
7 & $205-208$ & 35 & Ethanol & Brown & $\mathrm{C}_{24} \mathrm{H}_{20} \mathrm{~N}_{6} \mathrm{~S}_{4} \mathrm{O}_{7}$ \\
8 & $202-204$ & 40 & Ethanol & Black & $\mathrm{C}_{24} \mathrm{H}_{20} \mathrm{~N}_{4} \mathrm{~S}_{4} \mathrm{O}_{3} \mathrm{C}_{12}$ \\
9 & $260-262$ & 70 & Chloroform & Off white & $\mathrm{C}_{28} \mathrm{H}_{20} \mathrm{~N}_{6} \mathrm{~S}_{2} \mathrm{O}_{7} \mathrm{C}_{12}$ \\
10 & $270-272$ & 61 & Ethanol & White & $\mathrm{C}_{32} \mathrm{H}_{28} \mathrm{~N}_{6} \mathrm{~S}_{2} \mathrm{O}_{11}$ \\
11 & $244-246$ & 30 & Ethanol & Yellow & $\mathrm{C}_{32} \mathrm{H}_{28} \mathrm{~N}_{4} \mathrm{~S}_{2} \mathrm{O}_{7} \mathrm{C}_{12}$. \\
\hline
\end{tabular}

Synthesis of compound(2)[2-[(2-amino-4,5,6,7tetrahydro-1-benzothiophen-3-yl) sulfinyl] hydrazinecarbothioamide]:Compound $(1)(0.01 \mathrm{mo}$, $2.25 \mathrm{gm})$ and thiosemicarbazide $(0.01 \mathrm{~mol}, 0.91 \mathrm{~g})$ in ethanol $(30 \mathrm{ml})$ was reflexed for $(7 \mathrm{~h})$.The solvent was evaporated under reduced pressure and the viscous mass was poured over ice cold water,filtered and purification to give compound(2). M.P. $\left(109-112^{\circ} \mathrm{C}\right), \quad$ yield $(85 \%), \quad \operatorname{FTIR}\left(\mathrm{KBr}, v \mathrm{~cm}^{-1}\right)$ : $1178(\mathrm{C}=\mathrm{S}), \quad 1645(\mathrm{C}=\mathrm{O}), \quad 3402-3356\left(\mathrm{NH}_{2}\right), 3263$ $(\mathrm{NH}), \quad 2985-2897 \quad(\mathrm{CH})_{\mathrm{alph}}{ }^{1} \mathrm{HNMR} \quad(300 \mathrm{MHz}$, DMSO-d $\left.^{6}, \delta p p m\right): 8.70\left(\mathrm{~m}, 4 \mathrm{H}, \mathrm{NHNHCSNH}_{2}\right), 7.58$ $\left(\mathrm{S}, 2 \mathrm{H}, \mathrm{NH}_{2}\right) 1.75-2.72\left(\mathrm{~m}, 4 \mathrm{H}, \mathrm{CH}_{2}\right)$, Table $(2)$.

Synthesis of compound (3)[ 5-(2-amino-4,5,6,7tetrahydro-1-benzothiophen-3-yl)-1,3,4-

thiadiazol-2-amine]: Dissolve of compound(2) $(0.002 \mathrm{~mol}, 0.5 \mathrm{gm})$ in solution of $\mathrm{NaOH}$ $(0.0099 \mathrm{~mol}, 3.79 \mathrm{gm})$ in distilled water $(30 \mathrm{ml})$ at room temperature. The reaction was reflexed for (30 min.) after than kept overnight at $\left(5^{\circ} \mathrm{C}\right)$. The solid, thus separated was recrystallized from (ethanol+water) to give compound(3).M.P.(116$118 \mathrm{C})($ yield $=60 \%)$,FTIR $\left(\mathrm{KBr}, v \mathrm{~cm}^{-1}\right) \quad: 688(\mathrm{C}-\mathrm{S}-$ C), 1282(N-N), 1448(C-N),1575(C=N),3489-

3362 $\left(\mathrm{NH}_{2}\right),{ }^{1}$ HNMR(300MHz,DMSO-d ${ }^{6}, \quad$ Sppm): $5.75\left(\mathrm{~S}, 2 \mathrm{H}, \mathrm{NH}_{2}\right),(2.01-2.5)\left(\mathrm{m}, 4 \mathrm{H}, \mathrm{CH}_{2}\right), 1.7-$ $1.95\left(\mathrm{t}, 2 \mathrm{H}, \mathrm{CH}_{2}\right) \cdot$ Table $(2)$

General method for the synthesis of Schiff bases $(4,5)$ : A mixture of compound(2) $(0.002 \mathrm{~mol}, 0.54 \mathrm{~g})$ and $(0.004 \mathrm{~mol})$ of the (4chlorobenzaldehyde, 4-nitrobenzaldehyde) was added in absolute ethanol (20ml) refluxing for (10hrs). The mixture was cooled and the precipitate obtained purification from ethanol and chloroform. Table(2)

Synthesis of Compound(4):Yield50\%,M.P.(212214) ${ }^{\circ} \mathrm{C}, \mathrm{FTIR}\left(\mathrm{KBr}, v, \mathrm{~cm}^{-1}\right): 3228(\mathrm{NH}), 1687(\mathrm{C}=\mathrm{O})$ of amide, $1579(\mathrm{C}=\mathrm{N}), 3228(\mathrm{NH}), 1348,1523\left(\mathrm{NO}_{2}\right)$, $\mathrm{H}^{1} \mathrm{NMR}$ (300MHz,DMSO-d ${ }^{6}$,ppm): 11.7 (S,1H,NHCO), 8.08-8.61(m,10H,Ar-H,CH=N), 4.4( $\left.\mathrm{S},{ }_{1}^{1} \mathrm{H}, \mathrm{NH}\right), 1.3-1.8\left(\mathrm{~m}, 2 \mathrm{H}, \mathrm{CH}_{2}\right)$.

Synthesis of Compound(5):Yield43\%,M.P(230$232)^{\circ} \mathrm{C}, \quad$ FTIR3281(NH), $1680(\mathrm{C}=\mathrm{O}), 1591$, 1572(C=N), 790(C-Cl), H ${ }^{1}$ NMR(300MHz,DMSO$\left.\mathrm{d}^{6} \mathrm{~S}, \mathrm{ppm}\right):$ 9.91( $\left.\mathrm{S}, 1 \mathrm{H}, \mathrm{NHCO}\right), 5.5(\mathrm{~S} .1 \mathrm{H}, \mathrm{NH}), 8.37-$ 7.45(m, 20H, Ar-H.CH=N). Table(2)

Synthesis of compound(6): To a stirring of Schiff bases $4(0.001 \mathrm{~mol}, 0.5 \mathrm{~g})$ with sodium azide $(0.002 \mathrm{~mol}, 0.13 \mathrm{~g})$ and $(10 \mathrm{ml})$ tetrahydro furan (THF) was added. reaction was refluxed for (10Hrs.), after that the filtrate was cooled at room temperature the precipitation washed with cold water,purification from benzene,M.P(250$252)^{\circ} \mathrm{C}$,Yield69\%.FTIR:3360( $\mathrm{NH}$ of cyc lic),3221(NH),1604(C=C $)_{\mathrm{ar}}$, $1498(\mathrm{~N}=\mathrm{N}), 3055(\mathrm{C}-$ $\mathrm{H})_{\mathrm{ar}}$, 2127azidegroup. $\mathrm{H}^{1} \mathrm{NMR}(300 \mathrm{MHz}$, DMSO$\left.\mathrm{d}^{6}, \mathrm{Sppm}\right): 8.15-8.68(\mathrm{~m}, 8 \mathrm{H}, \mathrm{Ar}-\mathrm{H}), 4.3(\mathrm{~S}, 1 \mathrm{H}, \mathrm{NH}$ of tetrazole $), \quad 5.8(\mathrm{~S}, 1 \mathrm{H}, \mathrm{NH}), \quad 3.7(\mathrm{~S}, 1 \mathrm{H}, \quad \mathrm{C}-\mathrm{H} \quad$ of tetrazole), $\quad 1.3-1.78\left(\mathrm{~m}, 4 \mathrm{H}, \mathrm{CH}_{2}\right), \quad 2.69-2.72$ $\left(\mathrm{t}, 4 \mathrm{H}, \mathrm{CH}_{2}\right)$. Table $(2)$ 
General procedure for synthesis of compounds(7,8): A mixture of Schiff bases(4,5) $(0.001 \mathrm{~mol}),(0.002 \mathrm{~mol})$ of $\mathrm{SHCH}_{2} \mathrm{COOH}$ acid was in $(10 \mathrm{ml})$ of dry benzene and refluxed in water bath
for(4hrs.).The product was treated by $10 \%$ sodium bicarbonate to give compounds $(7,8)$ dried and recrystallization from suitable solvent. Table(2)

Table 2. Spectral data of the compounds (1-11).

\begin{tabular}{|c|c|c|c|c|c|c|c|}
\hline \multirow{2}{*}{$\begin{array}{c}\text { Comp. } \\
\text { No. }\end{array}$} & \multirow[b]{2}{*}{ Comp. Structure } & \multicolumn{6}{|c|}{ Characterization bands of FTIR $\left(\right.$ ATR,$\left.v \mathrm{mcm}^{-1}\right)$} \\
\hline & & $\begin{array}{c}\mathrm{C}- \\
\mathrm{H})_{\text {ali. }}\end{array}$ & $\begin{array}{l}\text { (C- } \\
\mathrm{H})_{\text {arom. }}\end{array}$ & $(\mathrm{C}=\mathrm{O})$ & $\begin{array}{c}(\mathrm{C}=\mathrm{N} \\
)\end{array}$ & $(\mathrm{C}=\mathrm{C})_{\text {arom. }}$ & Other bands $\mathrm{cm}^{-1}$ \\
\hline 1 & & $\begin{array}{l}2935- \\
2847\end{array}$ & ----- & 1734 of ester & ----- & $\begin{array}{c}1572 \\
1593 \\
\text { of thiophene ring }\end{array}$ & $\begin{array}{c}\mathrm{NH}_{2}(3396,3302) \\
\mathrm{C}-\mathrm{O}(1269) \\
\mathrm{C}-\mathrm{S}(673,738)\end{array}$ \\
\hline 2 & & $\begin{array}{l}2841- \\
2939\end{array}$ & ----- & $\begin{array}{l}1645 \text { of } \\
\text { amide }\end{array}$ & ----- & $\begin{array}{c}1533 \\
1620 \text { of } \\
\text { thiophene ring }\end{array}$ & $\begin{array}{c}\mathrm{NH}_{2}(3402,3356) \\
\mathrm{NH}(3298),(3169) \\
\mathrm{C}-\mathrm{N}(1153) \\
\mathrm{C}=\mathrm{S}(1178)\end{array}$ \\
\hline 3 & & $\begin{array}{l}2966- \\
2827\end{array}$ & ----- & ---- & $\begin{array}{l}1575 \\
1525\end{array}$ & $\begin{array}{l}1448 \\
1514\end{array}$ & $\begin{array}{c}\mathrm{NH}_{2}(3489,3362) \\
\mathrm{C}-\mathrm{S}(688,748)\end{array}$ \\
\hline 4 & & $\begin{array}{l}2918- \\
2839\end{array}$ & $\begin{array}{l}3074- \\
3009\end{array}$ & $\begin{array}{l}1687 \text { of } \\
\text { amide }\end{array}$ & $\begin{array}{c}1580 \\
\text { of } \\
\text { imine }\end{array}$ & $1446-1523$ & $\begin{array}{c}\mathrm{NH}(3228) \\
\mathrm{NO}_{2}(1523,1348) \\
\mathrm{C}=\mathrm{S}(1207)\end{array}$ \\
\hline 5 & & $\begin{array}{l}2982- \\
2806\end{array}$ & $\begin{array}{l}3049- \\
3097\end{array}$ & $\begin{array}{l}1680 \text { of } \\
\text { amide }\end{array}$ & $\begin{array}{c}1591 \\
1654 \\
\text { of } \\
\text { imine }\end{array}$ & $\begin{array}{l}1519 \\
1572\end{array}$ & $\begin{array}{l}\mathrm{NH}(3281) \\
\mathrm{C}-\mathrm{Cl}(1120) \\
\mathrm{C}=\mathrm{S}(1209)\end{array}$ \\
\hline 6 & & 2949 & $\begin{array}{l}3055- \\
3003\end{array}$ & 1672 & ------ & $\begin{array}{l}1473 \\
1533 \\
1604\end{array}$ & $\begin{array}{c}\mathrm{NH}(3260) \\
\mathrm{NH}(3360) \text { Of tetrazole } \\
\text { ring } \\
\mathrm{N}=\mathrm{N}(1498) \\
\text { Azide group }(2127) \\
\mathrm{NO}_{2}(1392,1500)\end{array}$ \\
\hline 7 & & $\begin{array}{l}2839- \\
2939\end{array}$ & 3169 & $\begin{array}{l}1705 \text { of } \\
\text { thiazolidine } \\
\text { ring } 1633 \text { of } \\
\text { amide }\end{array}$ & ---- & $\begin{array}{l}1531 \\
1560 \\
1591\end{array}$ & $\begin{array}{c}(\mathrm{C}-\mathrm{S}-\mathrm{C}) \\
759,661 \\
\mathrm{NH} \\
(3304)\end{array}$ \\
\hline 8 & & $\begin{array}{l}2852- \\
2926\end{array}$ & 3099 & $\begin{array}{l}1715 \text { of } \\
\text { thiazolidine } \\
\text { ring } 1660 \text { of } \\
\text { amide }\end{array}$ & ----- & $\begin{array}{l}1599 \\
1562 \\
1525\end{array}$ & $\begin{array}{c}(\mathrm{C}-\mathrm{S}-\mathrm{C}) \\
705,690 \\
\mathrm{NH}(3286)\end{array}$ \\
\hline 9 & & $\begin{array}{l}2854- \\
2976\end{array}$ & 3010 & $\begin{array}{l}1722 \text { of B- } \\
\text { Lactum } \\
1693 \text { of } \\
\text { amide }\end{array}$ & ----- & $\begin{array}{l}1568 \\
1595 \\
1637\end{array}$ & $\begin{array}{c}\mathrm{NO}_{2}(1518,1340) \\
\mathrm{C}-\mathrm{Cl}(1172) \\
\mathrm{NH}(3218)\end{array}$ \\
\hline 10 & & $\begin{array}{l}2856- \\
2995\end{array}$ & $\begin{array}{l}2061- \\
3090\end{array}$ & $\begin{array}{l}1737-1710 \\
\text { of oxazepine } \\
\text { ring } 1658 \text { of } \\
\text { amide }\end{array}$ & ---- & $\begin{array}{l}1527 \\
1575 \\
1595\end{array}$ & $\begin{array}{c}\mathrm{NO}_{2}(1336,1514) \\
\mathrm{NH}(3263) \\
\mathrm{C}-\mathrm{O}(1215) \\
\mathrm{C}-\mathrm{N}(1174)\end{array}$ \\
\hline 11 & & 2851 & 3176 & $\begin{array}{l}1749,1705 \\
\text { of oxazepine } \\
\text { ring } 1681 \text { of } \\
\text { amide }\end{array}$ & ----- & $1525-1635$ & $\begin{array}{l}\mathrm{NH}(3215) \\
\mathrm{C}-\mathrm{Cl}(1172) \\
\mathrm{C}-\mathrm{O}(1286) \\
\mathrm{C}-\mathrm{N}(1122)\end{array}$ \\
\hline
\end{tabular}

Synthesis of Compound(7): Yield35\%, M.P.(205$208)^{\circ} \mathrm{C}, \mathrm{FTIR}\left(\mathrm{KBr}, \mathrm{v}, \mathrm{cm}^{-1}\right) 1705(\mathrm{C}=\mathrm{O}$ of thiazolidine ring $), 1681(\mathrm{C}=\mathrm{O}$ of amide $), 3100(\mathrm{C}-\mathrm{H})_{\text {ar. }}$,29822922(C-H) aliph.,709,661(C-S-C), 3307(NH). $\mathrm{H}^{1} \mathrm{NMR}\left(300, \mathrm{MHz}, \mathrm{DMSO}-\mathrm{d}^{6}, \mathrm{Sppm}^{\mathrm{N}}\right.$ : 7.87-8.21 $\left(\mathrm{m}, 8 \mathrm{H}_{\mathrm{Ar}}\right) 5.6(\mathrm{~S}, 1 \mathrm{H}, \mathrm{NH}) 9.8(\mathrm{~S}$, $1 \mathrm{H}$, NHCO).1.68-2.74 $\left(\mathrm{m}, 4 \mathrm{H}, \mathrm{CH}_{2}\right), 2.75\left(\mathrm{~S}, 2 \mathrm{H}, \mathrm{CH}_{2}\right)$ of thiazolidinon ring. Table(2)
Synthesis of Compound (8):Yield40\%,m.p(202204 $)^{\circ} \mathrm{C}, \mathrm{FTIR}\left(\mathrm{KBr}, v, \mathrm{~cm}^{-1}\right): \quad 1715 \quad(\mathrm{C}=\mathrm{O} \quad$ of thiazolidine ring), $1682(\mathrm{C}=\mathrm{O}$ of amide),3098(CH)aromatic, 2900-2899(C-H) aliphatic, 32100 (NH),790(C-Cl). Table(2)

Synthesis of compound(9):To a stirred solution of compound(4)(0.001mol,0.5gm) ,tri methylamine 
$(0.002 \mathrm{~mol}, 0.202 \mathrm{gm})$ in dry dioxin $(15 \mathrm{ml})$ chloroacetylchloride $(0.002 \mathrm{~mol}, 0.226 \mathrm{gm})$ was added slowely in $(0-5)^{\circ} \mathrm{C}$ the component was then stirred for (6hrs.) after that poured into icewater.The precipitate was filtered and purification from chloroform. Yield 70\%, M.P: $260-262^{\circ} \mathrm{C}$, FTIR $\left(\mathrm{KBr}, v, \mathrm{~cm}^{-1}\right): 3200(\mathrm{NH}), 1722(\mathrm{C}=$ Ogroup,B-

Lactam), $1693\left(\mathrm{C}=\mathrm{O}\right.$ of amide). $\mathrm{H}^{1} \mathrm{NMR}(300 \mathrm{MHz}$, DMSO-d6,S, ppm): 7.74-8.66(m,8H,Ar-H), $5.0(\mathrm{~d}, 1 \mathrm{H}, \mathrm{N}-\mathrm{CH}), \quad 8.89(\mathrm{~S}, 1 \mathrm{H}, \quad \mathrm{NHCO}), \quad 2.2-3.9$ $\left(\mathrm{m}, 4 \mathrm{H}, \mathrm{CH}_{2}\right), \quad 1.7\left(\mathrm{t}, 2 \mathrm{H}, \mathrm{CH}_{2}\right), \quad 4.6(\mathrm{~S}, \mathrm{H}, \mathrm{NH})$, 5.44(d,1H,CH-Cl) Table (2)

General procedure for the synthesis of compounds(10,11): A mixture of Schiff bases $(4,5)(0.001 \mathrm{~mol})$ and $(0.002 \mathrm{~mol}, 0.29 \mathrm{gm})$ of phthalic anhydride was dissolving in $(10 \mathrm{ml})$ of dry benzene and refluxed in a water bath for(4hrs.). The product was treated with sodium bicar -bonate to produce

\section{Results and Discussion:}

The scheme 1 and 2 the proof of identify of synthetic sequence used our laboratories to make ready very important organic combination having compound(10,11)as a solid collected and recrystallized from $95 \%$ ethanol.

Synthesis of compound(10): Yield:61\%, M.P7.(270-272) ${ }^{\circ} \mathrm{C}, \mathrm{FTIR}\left(\mathrm{KBr}, v, \mathrm{~cm}^{-1}\right): 1737, \quad 1710$ $(\mathrm{C}=\mathrm{O}$ of oxazpine ring),1265(C-O),1174(C-N), (2856(C-H $)_{\text {aliph }}, 3090(\mathrm{C}-\mathrm{H})$ ar. $\mathrm{H}^{1} \mathrm{NMR} \quad(300 \mathrm{MHz}$, DMSO-d6, S,pmm):7.13-8.15(m,18H,Ar-H), 7.03 (S,1H,C-H of oxazpine ring), $8.85(\mathrm{~S}, 1 \mathrm{H}, \mathrm{NHCO})$, $4.9(\mathrm{~S}, 1 \mathrm{H}, \mathrm{NH}), 2.01-2.2\left(\mathrm{~m}, 4 \mathrm{H}, \mathrm{CH}_{2}\right), 1.7\left(\mathrm{t}, 2 \mathrm{H}, \mathrm{CH}_{2}\right)$. Table(2)

Synthesis of compound(11): Yield:30\%, M.P:(244-246) ${ }^{\circ}$ C.FTIR (KBr, v, $\left.\mathrm{cm}^{-1}\right): 1726,1699$ $(\mathrm{C}=\mathrm{O}$ of oxazpine ring),1233(C-O),1170(CN), 2860(C-H $)_{\text {aliph }}, 3100(\mathrm{C}-\mathrm{H})_{\mathrm{ar}}$. $\mathrm{H}^{1} \mathrm{NMR}(300 \mathrm{MHz}$, DMSO-d $\left.{ }^{6}, \mathrm{~S}, \mathrm{pmm}\right): \quad 7.0-8.4(\mathrm{~m}, \quad 18 \mathrm{H}, \mathrm{ArH}), \quad 6.93$ (S,1H,C-H of oxazpine ring), 1.3-1.78 (m, $\left.4 \mathrm{H}_{2} \mathrm{CH}_{2}\right)$, 2.69-2.72(t,4H, $\left.\mathrm{CH}_{2}\right)$. Table(2)

wide spectrum of biological activities. The target of this work was performed by following different strategic, the synthesis routes used in shown in scheme(1).

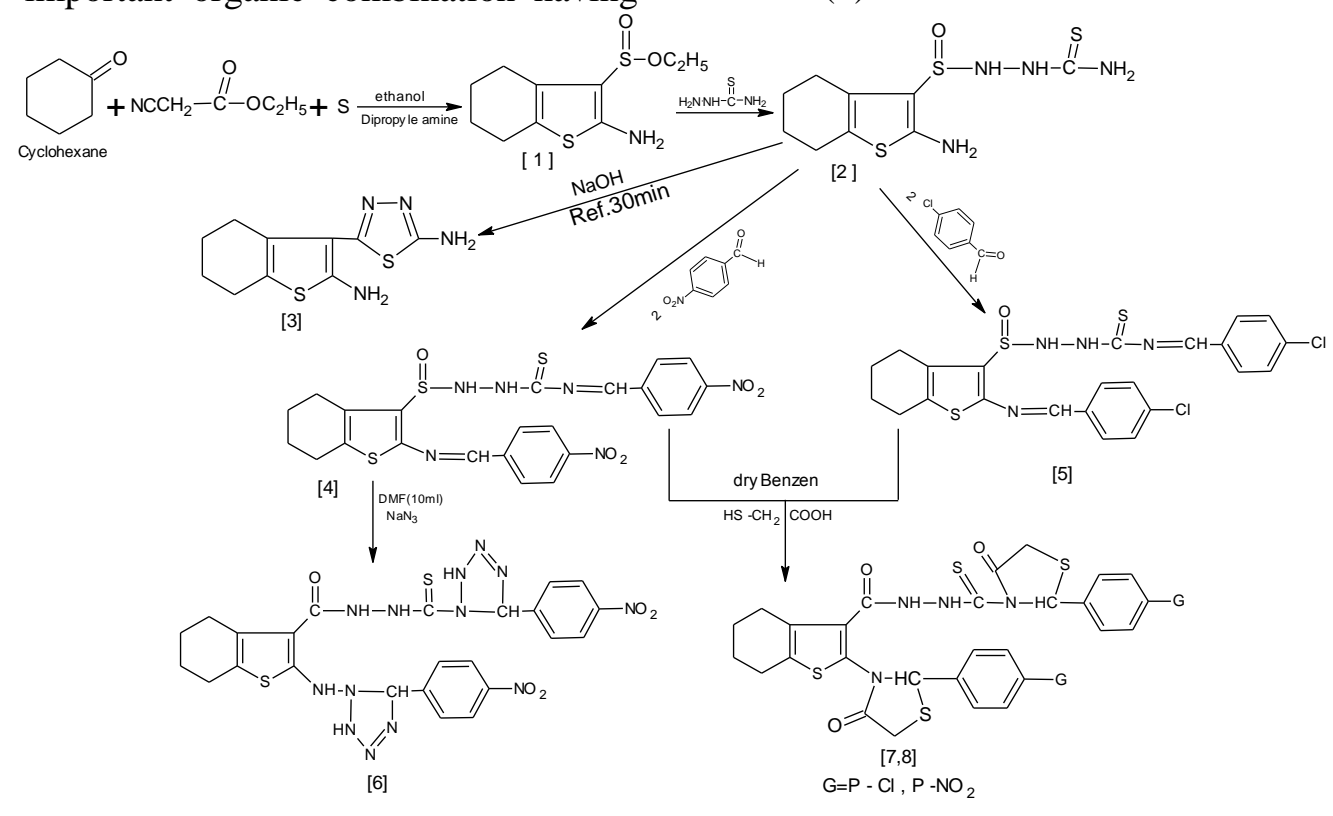

Scheme 1
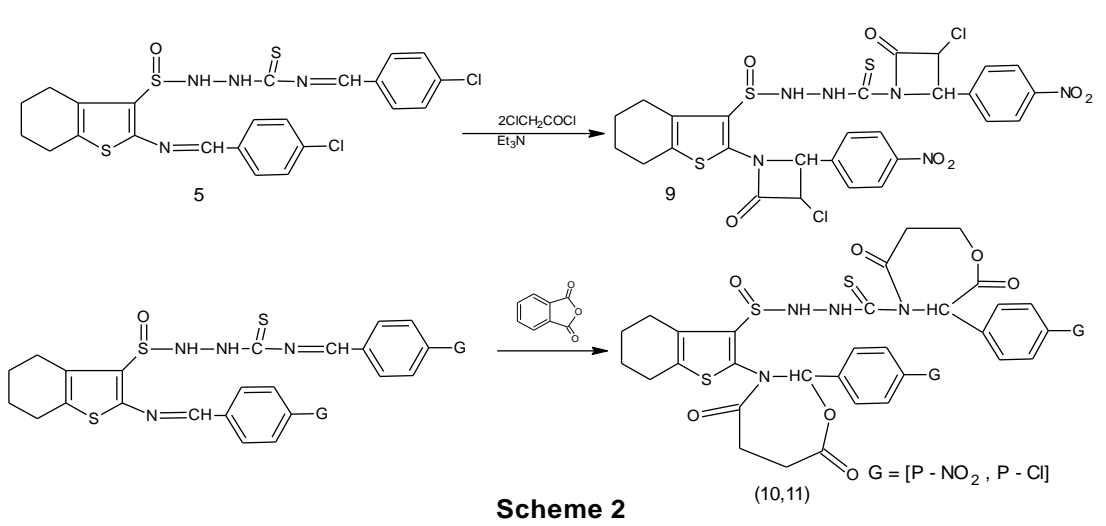
The derivative(1)2-amino-3-carbethoxy4,5,6,7-tatrahydrobenzothiophe-ne was synthesized by the react cyclohexanone with ethyl cyanoacetate and sulfur.The structu -re of derivative 1 with clause by presence by IR spectrum of $\mathrm{NH}_{2}$ group at $3302,3396 \mathrm{~cm}^{-1}$ and carbonyl group $(\mathrm{C}=\mathrm{O})$ of ester at $1734 \mathrm{~cm}^{-1} \cdot \mathrm{H}^{1} \mathrm{NMR}$ of compound $1: 1.25\left(\mathrm{t}, 3 \mathrm{H},-\mathrm{CH}_{3}\right.$ ester) ,4.30 $\left(9,2 \mathrm{H},-\mathrm{CH}_{2} \mathrm{O}-\right) 5.5\left(\mathrm{~S}, 2 \mathrm{H}, \mathrm{NH}_{2}\right)$. The mass spectrum of the derivative1showed the mole -cular ion peak atZ $=225\left(\mathrm{M}^{+}, 100 \%\right)$ is in accord with the molecular formula of this compound, $\mathrm{C}_{11} \mathrm{H}_{15} \mathrm{NS}$, (225g/mol)Fig. 1 .

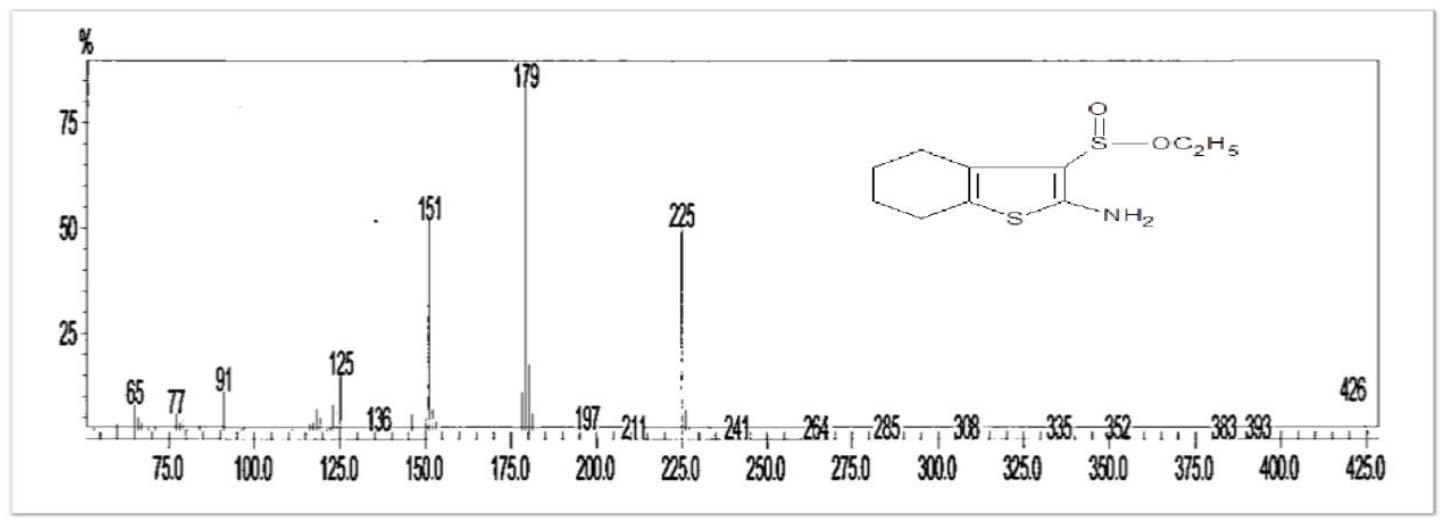

Figure 1. The mass spectrum of compound(1)

When derivative 1 react with of $\mathrm{NH}_{2}$ at $3402,3356 \mathrm{~cm}^{-1}$ and $(\mathrm{C}=\mathrm{O})$ of amide at thiosemicarbazide gave derivative 2, Fig. 2 the IR $1645 \mathrm{~cm}^{-1}$. The ${ }^{1}$ HNMRof derivative2exhibited spectrum showed disappearance of the $(\mathrm{C}=\mathrm{O})$ band signals at $8.70\left(\mathrm{~m}, 4 \mathrm{H}, \mathrm{NHNHCSNH}_{2}\right)$, of ester at $1734 \mathrm{~cm}^{-1}$ and appearance of double bands $7.58\left(\mathrm{~S}, 2 \mathrm{H}, \mathrm{NH}_{2}\right)$.

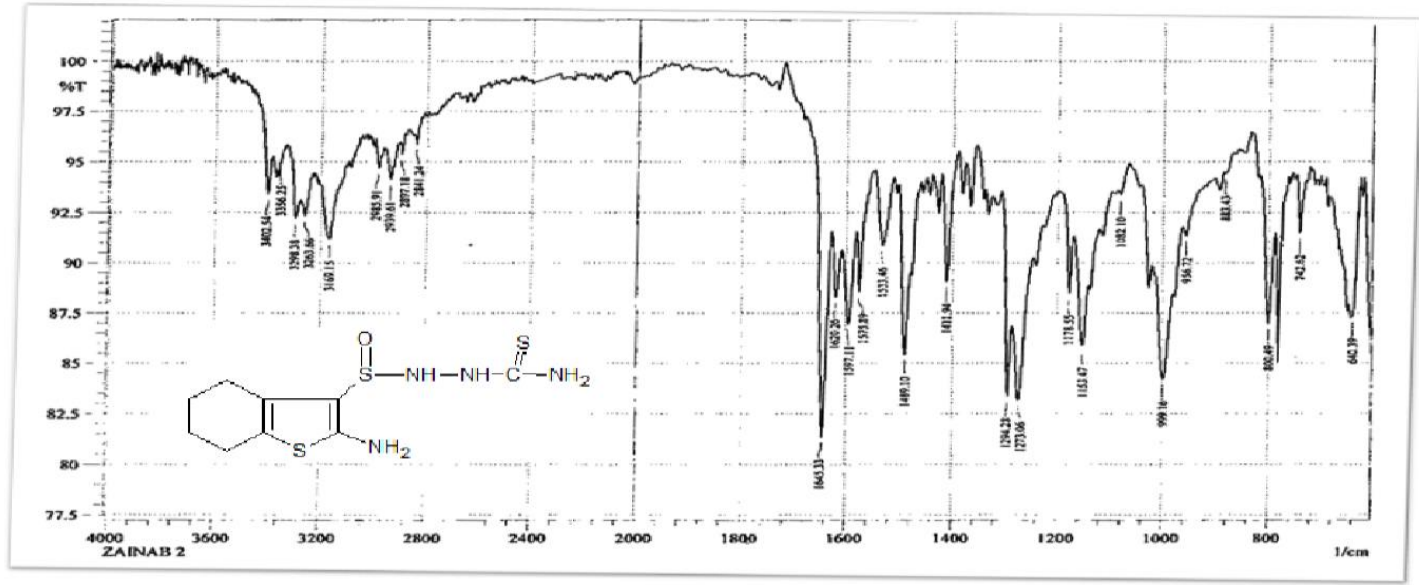

Figure 2. The FTIR spectrum of compound(2)

Reac -tion between derivative 2 and $\mathrm{NaOH}$ solution afforded thiadazole derivatives 3 . The spec -trum of derivative 3 showed the disappearance of absorption bands to $(\mathrm{C}=\mathrm{O})$ of amide with appearance of the $(\mathrm{C}=\mathrm{N})$ at $1575 \mathrm{~cm}^{-1}$ and $(\mathrm{N}-\mathrm{N})$ at $1282 \mathrm{~cm}^{-1}$. The ${ }^{1} \mathrm{HNMR}$ of compound 3 show -ed singlet signal at5.75ppm for $\mathrm{NH}_{2}$. Fig. (3) 


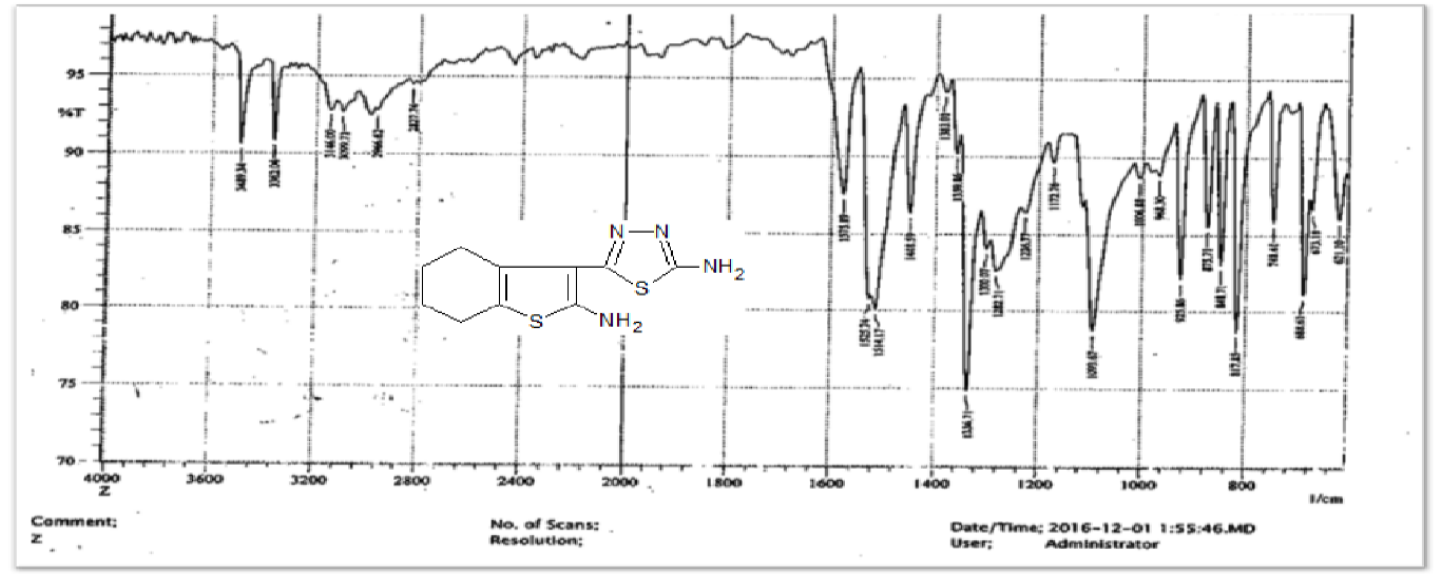

Figure 3. The FTIR spectrum of compound (3)

Fig. 4 condensation of derivative 2 with various substituted benzaldehyde in absolute ethanol gave arylidine derivatives $4 \& 5$.

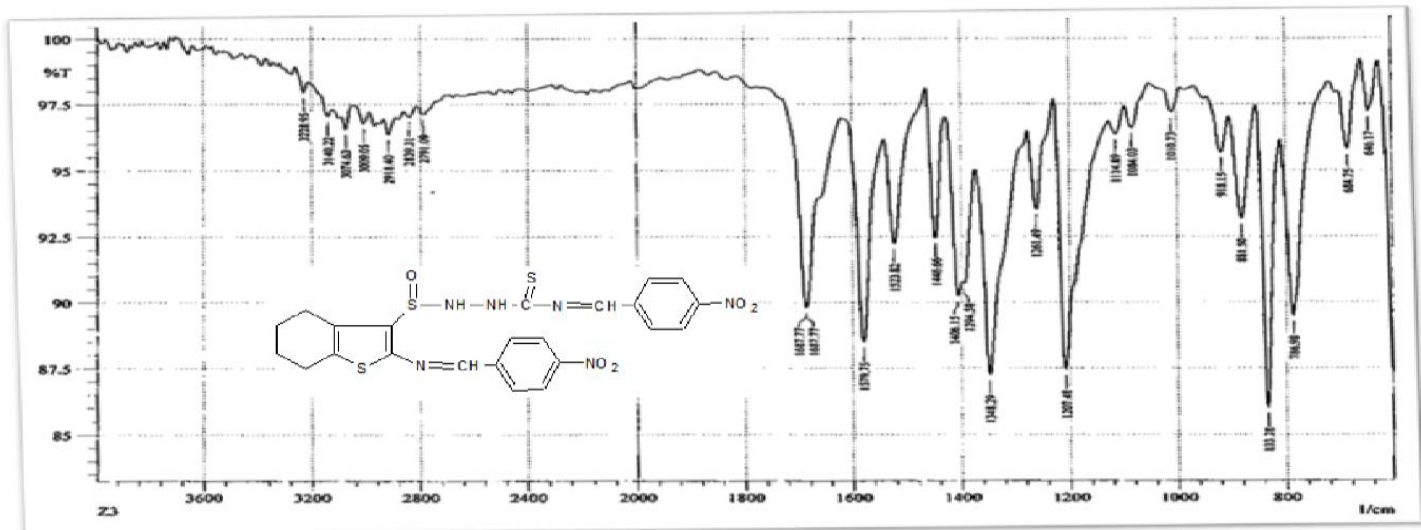

Figure 4. The FTIR spectrum of compound(4).

The creation of these azomethines show that by the presence in the IR spectra of $(\mathrm{CH}=\mathrm{N})$ stretching bands at $1580-1600 \mathrm{~cm}^{-1}$ add together the disappearance of $\mathrm{NH}_{2}$ stretching bands. The $\mathrm{H}^{1} \mathrm{NMR}$ of compound 5 fig. 5 display singlet signals at $9.91 \mathrm{ppm}$ was attributed to NHCO,5.5(S,1H,NH), amultiplet signals at8.37$7.45 \mathrm{ppm}$ which belonged to aromatic protons and $(\mathrm{N}=\mathrm{CH}), 2.01-2.5 \quad\left(\mathrm{~m} .4 \mathrm{H}, \mathrm{CH}_{2}\right), \quad$ 1.7$1.95\left(\mathrm{t}, 2 \mathrm{H}, \mathrm{CH}_{2}\right) 22$ fig. 4 compound4, Schiff bases were building in water bath at $\left(70-75^{\circ} \mathrm{C}\right)$ with $\mathrm{NaN}_{3}$ in dimethyl furan, to give compound6, IR spectroscopy was used characterize structure of the synthesized compound. The tradition of bands at $1579 \mathrm{~cm}^{-1}$, ascribe to $(\mathrm{C}=\mathrm{N})($ imine group) stretching frequency is favor proof for the success of this step. It also, IR spectra for this derivative were appears of a strong band at $2127 \mathrm{~cm}^{-1}$ characteriza -tion stretching frequency of azide group, bands at $1498 \mathrm{~cm}^{-1}$ were caused by the $\operatorname{cyclic}(\mathrm{N}=\mathrm{N})$ stretching of tetrazole circular band.

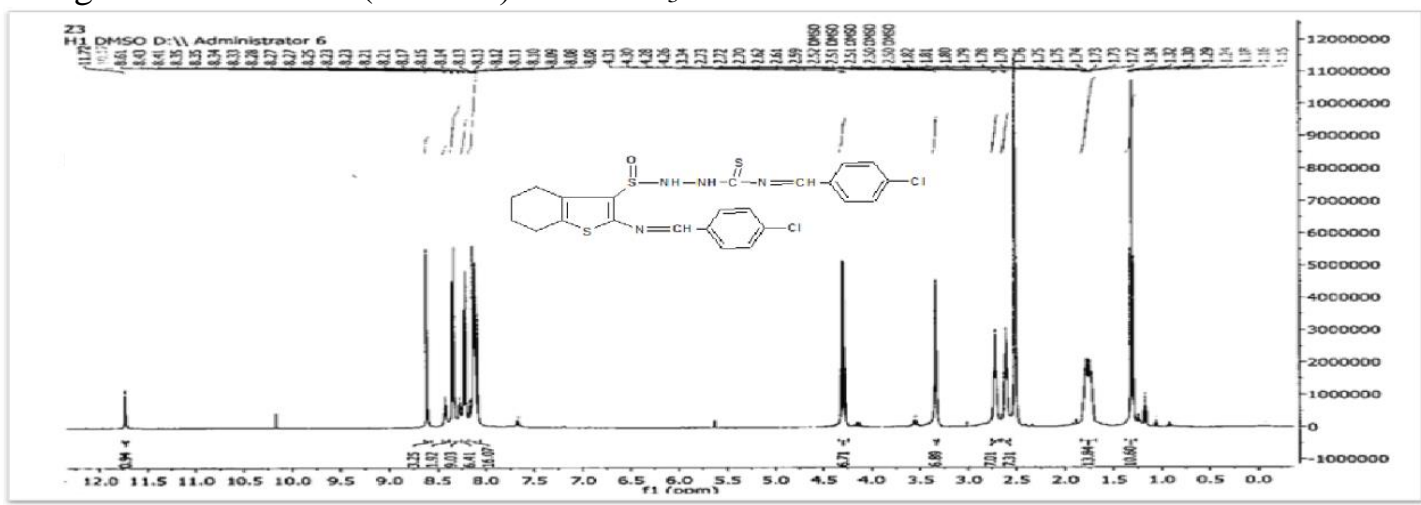

Figure 5. The $H^{1}$ NMR spectrum of compound (5) 
Band at $\left(3360 \mathrm{~cm}^{-1}\right)$ because of $(\mathrm{N}-$ H)group. $\mathrm{H}^{1} \mathrm{NMR}$ spectrum of compound6 shows the following characteristic, the aromatic ring protons as multiple at $8.15-8.68 \mathrm{ppm}$ which belonged to aromatic protons and $(\mathrm{N}-\mathrm{H})$ proton for tetrazole appeared at $4.3 \mathrm{ppm}$ singlet, signal at 3.7 ppmdue to the $(\mathrm{C}-\mathrm{H})$ proton in tetrazole ring fig 6 . Cyclization of derivatives $4 \& 5$ with thioglycolic acid in the presence of dry Benzene afforded derivatives $(7,8)$. FTIR of compounds shows the arrival of stretching strip of $(\mathrm{C}=\mathrm{O})$ group at $1705,1715 \mathrm{~cm}^{-1}$ expected thiazolidine one ring and this was the almost all characteristic evidence for the success of cyclization step. Other typical bands of aromatic system is the showed ofv $(\mathrm{C}=\mathrm{C})$ at $\operatorname{about}\left(1581 \mathrm{~cm}^{-1}\right), \mathrm{v}(\mathrm{C}-\mathrm{S}-\mathrm{C})$ at $709,661 \mathrm{~cm}^{-1} \mathrm{H}^{1} \mathrm{NMR}$ of derivative7 showed singlet signal at(2.75ppm)was attributed to $\left(\mathrm{CH}_{2}\right)$ of thiazolidine ring a multiplet broach cast signal at 7.87 \&8.21ppmthat has belonged to aromatic protons, singlet signals at $9.8 \mathrm{ppm}$ which was assigned to NHCO,5.6 ppm was characteristic to N$\mathrm{H}$ proton. Fig.7. Handing of derivative4with trimethyl amine and chloroacetyl chloride provide azeti -dinyl compound9.

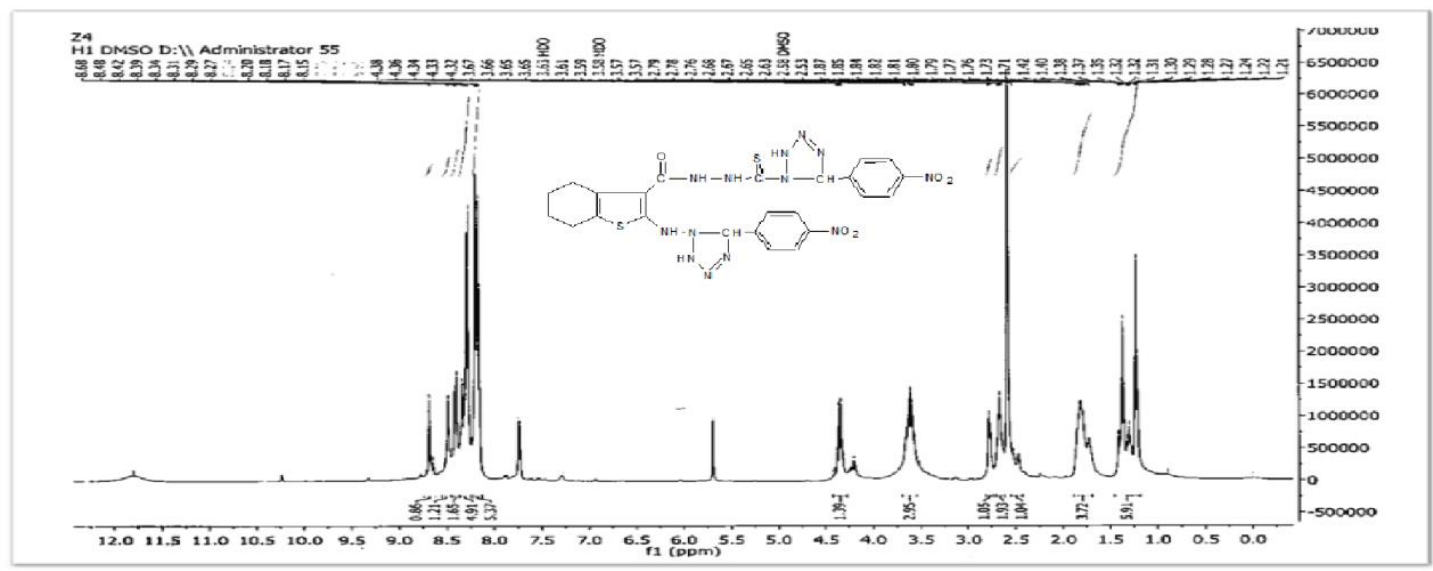

Figure 6. The $\mathrm{H}^{1} \mathrm{NMR}$ spectrum of compound (6)

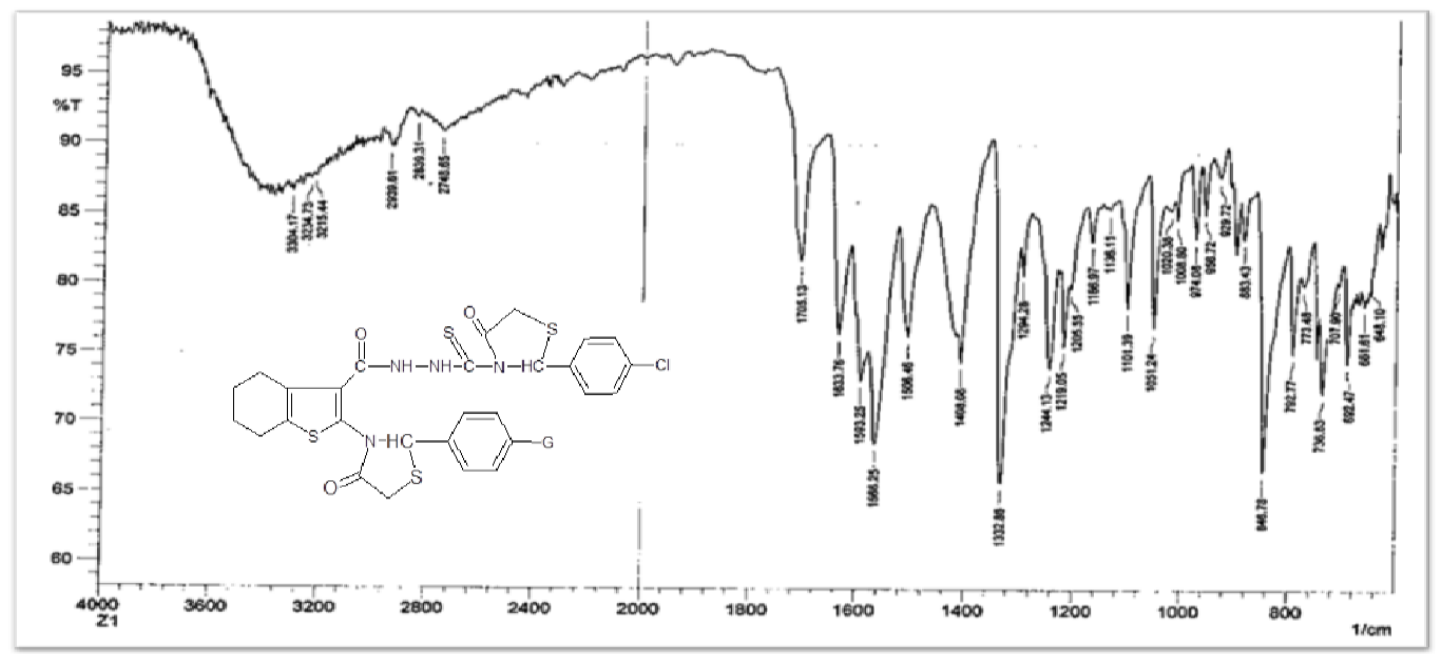

Figure 7. The FTIR spectrum of compound (7)

The structure of compound 9 install by IR spectral data which was display the vanishing band of $(\mathrm{CH}=\mathrm{N})$ in the area $1579 \mathrm{~cm}^{-1}$ united with the looks of absorption band at $1722 \mathrm{~cm}^{-1}(\mathrm{C}=\mathrm{O})$ of B-Lactam). The ${ }^{1} \mathrm{HNMR}$ of derivative 9 make visible signals at (5.0-5.44ppm) due to azetidinyl ring proton, a multiblet signals at $7.74 \& 8.66$ due to aromatic protons. Fig.8 .Fig. 9. Schiff bases $4 \& 5$ react with cyclic anhydrides to give the corresponding addition product. 


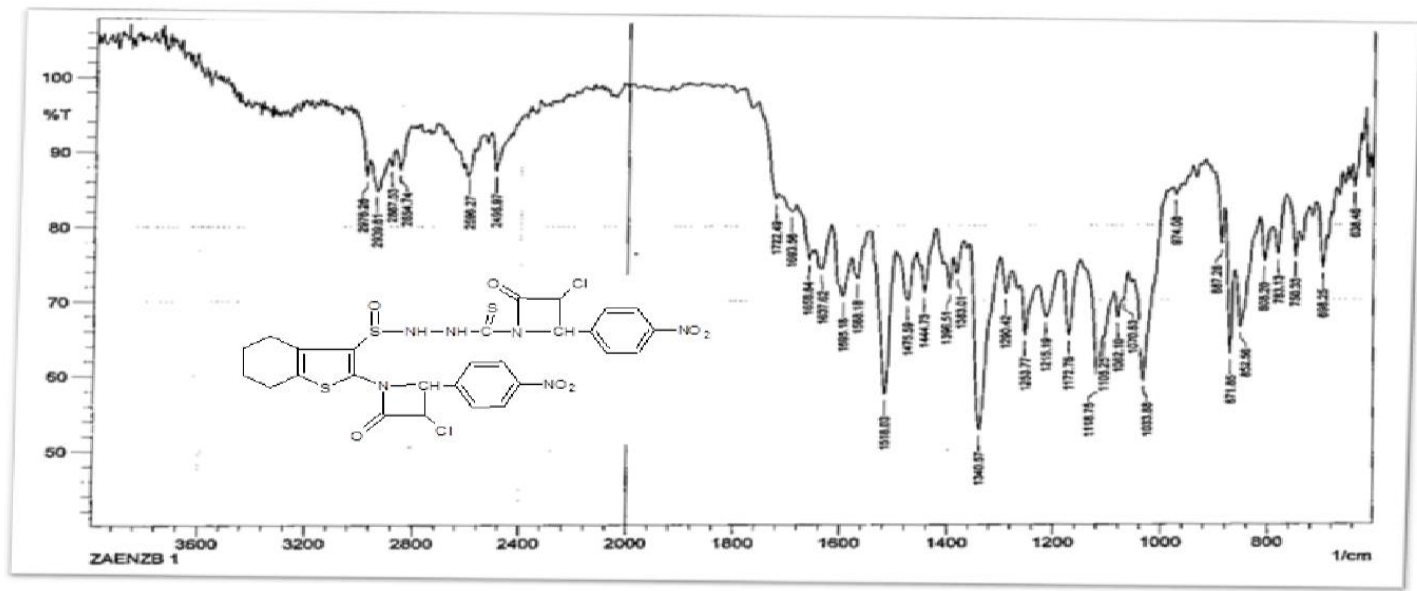

Figure 8. The FTIR spectrum of compound (9)

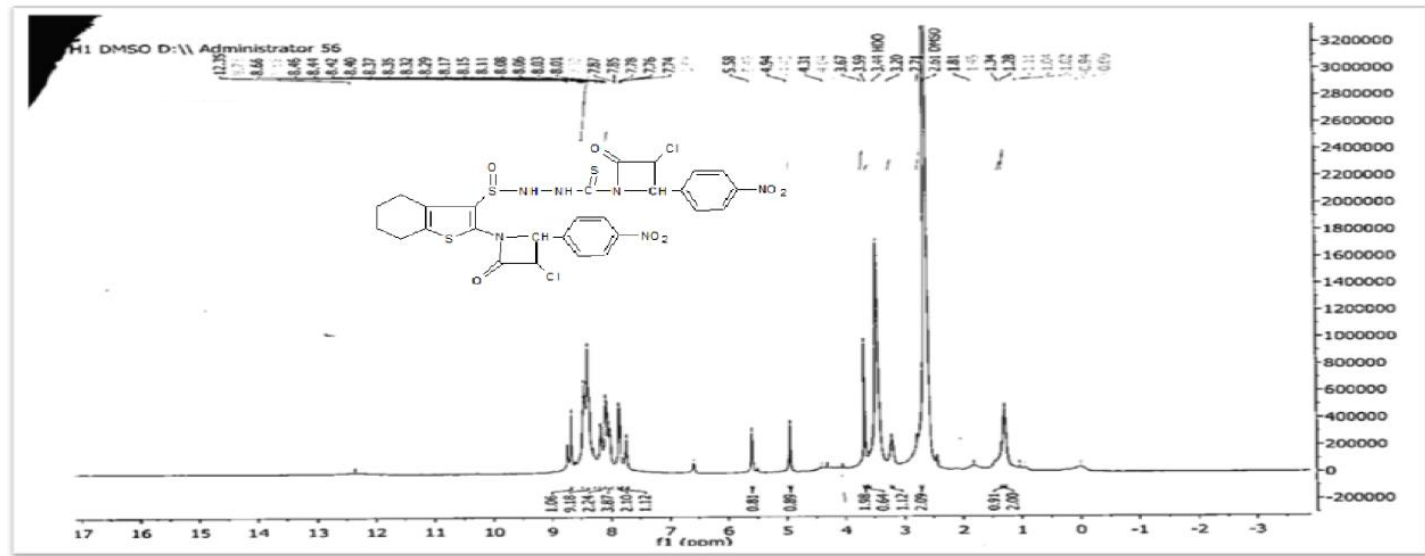

Figure 9. The $\mathbf{H}^{1} \mathrm{NMR}$ spectrum of Compound(9).

As a sequence, expected to react with phthalic anhydride to produce oxazepine compounds $10 \&$ 11.The IR spectral of compound point to the looks of $(\mathrm{C}=\mathrm{O})$ group band at $1737 \& 1726 \mathrm{~cm}^{-1}$ and $(\mathrm{C}-\mathrm{O})$ band at $\left(1265 \mathrm{~cm}^{-1}\right)$ and (C-N) band at (1174) $\mathrm{cm}^{-1} \cdot \mathrm{H}^{1} \mathrm{NMR}$ of compound11 showed singlet signals at $(6.93 \mathrm{ppm})$ was attributed to $\mathrm{C}-\mathrm{H}$ proton of oxazpine ring, multiple signals at $7.0-8.4 \mathrm{ppm}$ which belonged to aromatic protons. Table2.

\section{Antimicrobial Activity:}

The antimicrobial activity of the 2-amine-3cabethoxy-4, 5, 6, 7-tetrahydrobenzothiophene derivatives (2-11) were test by the agar discdiffusion method against two $\left(\mathrm{G}^{+}\right)$staphylococcus aureus and staphylococcus epidermidisa and two (G-) bacteria E.Coli, Klebsiell as microorganism and fungal strains namely candida albicans. Dimethyl sulfoxide DMSO was used as solvent.

The test was commit at $(100 \mu \mathrm{gm} / \mathrm{ml})$ conc.

The bacteria and fungi were carried out in agar and potato dextrose agar medium and these plate were incubated for $24 \mathrm{hrs}$. for bacteria and $48 \mathrm{hrs}$.for fungi at $37^{\circ} \mathrm{C}$.

Table 3. Antimicrobial evaluation of compounds.

\begin{tabular}{|c|c|c|c|c|c|}
\hline \multirow{3}{*}{$\begin{array}{l}\text { Synthesized } \\
\text { compounds }\end{array}$} & \multicolumn{5}{|c|}{ Inhibition Zone $(\mathrm{mm})$ at $100 \% \mu \mathrm{mg} / \mathrm{mL}$} \\
\hline & \multicolumn{2}{|c|}{ Grampositive } & \multicolumn{2}{|c|}{ Gramnegative } & \multirow{2}{*}{$\begin{array}{c}\text { Fungi } \\
\text { C.albican us }\end{array}$} \\
\hline & S.aureus & S.epider midis & E.Coli & Klebsiell aspp & \\
\hline 2 & ---- & 15 & 23 & 13 & 20 \\
\hline 3 & 9 & 14 & 18 & ---- & ---- \\
\hline 4 & ----- & 12 & 23 & ---- & 19 \\
\hline 5 & 18 & 10 & 21 & 10 & ----- \\
\hline 6 & 13 & 10 & 22 & 14 & 15 \\
\hline 7 & ----- & 18 & 21 & 20 & 17 \\
\hline 8 & 20 & 15 & 18 & 22 & 15 \\
\hline 9 & 19 & 20 & 23 & 19 & 21 \\
\hline 10 & 22 & 18 & 11 & 14 & 15 \\
\hline 11 & 17 & 11 & 12 & 19 & ------ \\
\hline Amoxicillin & 17 & 19 & 16 & 17 & 21 \\
\hline
\end{tabular}




\section{Antimicrobial Activity:}

In this study it has been used the amoxicilline drugs as standard antibacterial for comparision with the benzothiophene derivatives that is (Schiff base, azetidinone, thiazolidinone and oxazepan). The results of these compounds are summarized in table(3). It could be observed that all the tested compounds were active towards sepidermidis and compounds (7.9.10)show high activity. All the test compounds were active towards saureus except $(2,4,7)$ while compounds $(8,10)$ show high activity, so only compounds $(7,8,9,11)$ were active toward klebiellaspp. On the other hand, All compounds (2-9) has high inhibition toward E.Coli except compounds $(10,11)$ has low inhibition on this kind of bacteria. In addition compounds $(2,4,7,9)$ showed high inhibition candida Fungi.

\section{Conclusion:}

The terahydrobenzo thiophene derivatives were prepared and characterization by spectral and four strains of bacteria namely is epidmides S.Aureus as (G+), E.Coli and Klebsiellla SPP as (G-), and it has been comparision with Amoxicillin as caliber drug to reveal the potency of synthesized derivatives. The fungi and bacteria found to be sensitive to all derivatives at lower concentration $(100 \mu \mathrm{mg} / \mathrm{mL})$ but no sensitivity at lower concentration.

\section{Conflicts of Interest: None.}

\section{References:}

1. Ajeet Ak, Mishra NA, Recent Adrances in Development of thiophene Deriratives and theirpharmacological Effectts Am. J.pharm. Sci.2015;3(1):18-24.

2. Abdul Jabar KH, Suhair SM. Synthesis and Antibacterid Activities of new 3-Amino-2-methylQuinazolin-4(3h)- one Derivatives. American J.chem.2012;2(3):150-156.

3. Chowki AA, Magdum CS, Ladda PL,Mohite Sk. Synthesis and antitubereular activity of 6-nitro-2[4formy1-3-(substituted)phenyl] phrazol-1-y1) benzothiazoles. Int. J. chem. sci. 2008;6(3):16001605 .

4. Abdul Jabar KH, Mohammed FM, Muayad AQ. Antifungal Activity and Imidazole derivatves. Int. sci. J. Theo \& Appli sci. 2016; 34 (8):65-78.

5. Ramprasad SM, Sarsathy TS, Niraimathi VE, Indhumathi BM. Antimicrobial activity of some hetero benzocaine derivatives .Inter .J. pharm. And Pharm.Sci.2012; 23(9);1157-1179.

6. Kristina SA,Marijeta KM, Iro PN, LidiJa SA. Synthesis and Photochemical synthesis DNA binding and antitumor eraluationd of novel cyano and amidino substituted derivate of naphtha furans and naphtha thiophenes. Eur. J. med. chem. 2006;2(41): 925-939.

7. Vitalino SM, Lafaytte EA,Oliveira TB, Eandmoura RO. Synthesis DNA Binding and AniPro liferative Activity of norel Acridine thiose micarbazone Derivatives. Int .J. mol Sci. 2015;16(4):13023-13042.

8. Sabir HJ,Mohd AE, Ashraf MA. Synthesis, characterization and biological activity of Schiff bases.E.J chem .2008; 5(4) :963-968.

9. Singh IM, Kaur HI, Kumar SN, Lata SJ 1. synthesis and antibacterial activity of 3-chloro-4-subs tituted phenyl azetialnonly, thiazolidinonyl-1,3oxazole Inter. J. pharm. sci. and Research .2010:1(2)148-168.

10. Nicholas PK, Michael RZ. De composition of Aminotetrazole Based Energetic materials under High Heating Rate conditions. J.phys.chem. 2012; 116(6):1519-1526.

11. Muzammi TP,khetani DB. Synthesis and characterization of Schiff base m-nitro aniline and their complexes. Res. J. chem. sci.2015;5(5):52-55.

12. Indu SH, Arun KM. Synthesis and Antimicrobial activity of various Quinazolin one derivatives containting thiazole and thiazoldinone moiety. Int. J. chemTech Res. 2014; 6(5):9.

13. Firyal WA, Salma AA,Redha IA, Hanaa AA. Synthesis and biological evaluation of new quinazolinone deriratives.Eur.J.Med.chem.2014;5(4): 628-634.

14. Enis NM, Thahira BS, Edward RT, Karen AC. Synthesis, characterization and biological evaluation of transition metal complexes derived from edentate ligands. Int. J.mol. sci.2015;16(5):11034-11054.

15. Ganguri KM, Sudhakar RO. Synthesis and antibacterial activity of 3-phenyl substituted uinazolinone .IJRPC.2015;5(3):470-474.

16. Pradeep KS, chandrakant PS, Anand KH. The chemistry and pharmacological potential of 2aztidinnone.In corporate with halogen atoms and cyano group .Review world J. pharm.Sci.2016;5(3): 433-455.

17. NaIk TA, ChIKalk HM. Studies on synthesis of pyrimidine derivatives and their pharmacological evaluation. J.chem. 2007;4(1): 60-66.

18. Verma AM, Sarf SK .4-thiazolidnone biologically active scaffold .Eur.J.med.Chem. 2008; 43(5): 897968.

19. Stefania FB, Gabriel SB, Gabriela LA, Constantin DH. New hetro cyclic compounds from 1,2,4-triazole and 1,3,4-thiadiazole class bearing diphenlsu fone moieties synthesis, characterization and antimicrobial activity evaluation Eur.J.med. chem. 2012 mar; 49(5):417-42.

20. Dubey AE, Srivastava SK, Srivastava SD. conventional and micro ware assisted synthesis of 2oxo substituted aryl azetidine derivatives of benzotriazileanew class of biological compounds. Bio.med.chem .2011;21(3):569-573. 
تحضير واختبار الفعالية البكتيرية لمشتقات 7.6.5.4 - تتراهايدرو بنزوثيوفين الجديدة

اسماء محمد عبدالله

زينب زهير محمد علي

قسم الكيمياء، كلية العلوم، الجامعة المستتصرية، بغداد، العراق.

مجموعة من مشتقات التتراهيدروبنزوثايوفين تعمل حلقات غير منجانسة مختلفة مثل قواعد شيف، 2-ازيتيدينون ،

الخلاصة :

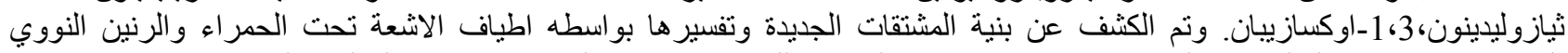

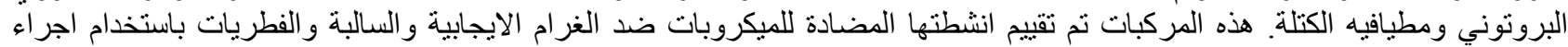
التخفيف الجزيئي.

الكلمات المفتاحية : تتر اهايدروثايوفين، الفعالية البايولوجية، ثايادايازول، قاعدة شيف، تترازول،2-ازيتيدانون،4-ثايازوليدون،3-اوكسازيين. 